University of Nebraska - Lincoln

DigitalCommons@University of Nebraska - Lincoln

Nebraska Cooperative Fish \& Wildlife Research Nebraska Cooperative Fish \& Wildlife Research Unit -- Staff Publications

$10-2012$

\title{
Using the Internet to Understand Angler Behavior in the Information Age
}

\author{
Dustin R. Martin \\ University of Nebraska-Lincoln, dustin.martin@huskers.unl.edu \\ Brenda M. Pracheil \\ University of Wisconsin-Madison, pracheilbm@ornl.gov \\ Jason A. DeBoer \\ University of Nebraska-Lincoln, fish_hedd@yahoo.com \\ Gene R. Wilde \\ Texas Tech University, gwilde@ttu.edu \\ Kevin L. Pope \\ University of Nebraska-Lincoln, kpope2@unl.edu
}

Follow this and additional works at: https://digitalcommons.unl.edu/ncfwrustaff

Part of the Other Environmental Sciences Commons

Martin, Dustin R.; Pracheil, Brenda M.; DeBoer, Jason A.; Wilde, Gene R.; and Pope, Kevin L., "Using the Internet to Understand Angler Behavior in the Information Age" (2012). Nebraska Cooperative Fish \& Wildlife Research Unit -- Staff Publications. 102.

https://digitalcommons.unl.edu/ncfwrustaff/102

This Article is brought to you for free and open access by the Nebraska Cooperative Fish \& Wildlife Research Unit at DigitalCommons@University of Nebraska - Lincoln. It has been accepted for inclusion in Nebraska Cooperative Fish \& Wildlife Research Unit -- Staff Publications by an authorized administrator of DigitalCommons@University of Nebraska - Lincoln. 


\section{Using the Internet to Understand Angler Behavior in the Information Age}

\section{Dustin R. Martin}

Nebraska Cooperative Fish and Wildlife Research Unit and School of Natural Resources, University of Nebraska, Lincoln, NE 68583. E-mail: dustin.martin@huskers.unl.edu

\section{Brenda M. Pracheil}

Center for Limnology, University of Wisconsin-Madison, Madison, WI 53706

\section{Jason A. DeBoer}

Nebraska Cooperative Fish and Wildlife Research Unit and School of Natural Resources, University of Nebraska, Lincoln, NE 68583

\section{Gene R. Wilde}

Department of Biological Sciences, Texas Tech University, Lubbock, TX 79409

\section{Kevin L. Pope}

U.S. Geological Survey-Nebraska Cooperative Fish and Wildlife Research Unit, and Professor, School of Natural Resources, University of Nebraska, Lincoln, NE 68583

ABSTRACT: Declining participation in recreational angling is of great concern to fishery managers because fishing license sales are an important revenue source for protection of aquatic resources. This decline is frequently attributed, in part, to increased societal reliance on electronics. Internet use by anglers is increasing and fishery managers may use the Internet as a unique means to increase angler participation. We examined Internet search behavior using Google Insights for Search, a free online tool that summarizes Google searches from 2004 to 2011 to determine (1) trends in Internet search volume for general fishing-related terms and (2) the relative usefulness of terms related to angler recruitment programs across the United States. Though search volume declined for general fishing terms (e.g., fishing, fishing guide), search volume increased for social media and recruitment terms (e.g., fishing forum, family fishing) over the 7-year period. We encourage coordinators of recruitment programs to capitalize on anglers' Internet usage by considering Internet search patterns when creating web-based information. Careful selection of terms used in web-based information to match those currently searched by potential anglers may help to direct traffic to state agency websites that support recruitment efforts.

\section{INTRODUCTION}

Declining participation in outdoor activities is a pervasive concern in the United States (Kareiva 2008; Pergams and Zaradic 2008), garnering attention from a wide range of authorities

\section{El uso de internet para comprender el comportamiento de los pescadores en la era de la informática}

RESUMEN: La declinación para participar en la pesca recreativa es un problema considerable para los manejadores de pesquerías, ya que la venta de licencias de pesca es una importante fuente de ingresos destinada a la protección de recursos acuáticos. Esta declinación con frecuencia se le atribuye, en parte, a que la sociedad depende cada vez más de la electrónica. El uso de internet por parte de los pescadores se está incrementando y los manejadores pesqueros pueden usar internet como un medio único para aumentar la participación de los éstos. Se examinó el comportamiento de búsqueda en internet mediante Google Insights, una herramienta en línea que resume las búsquedas hechas en Google durante el periodo 2004-2011, con el fin de determinar (1) tendencias en internet del volumen de búsqueda de términos generales relativos a la pesca, y (2) la utilidad relativa de términos relativos a programas de reclutamiento de pescadores, a lo largo de los EEUU. Los resultados apuntan a que a lo largo de un periodo de siete años si bien disminuyó el volumen de búsqueda de términos generales de pesca (p.e. pesca, guía de pesca), incrementó el volumen de búsqueda de medios sociales y términos relacionados al reclutamiento (p.e. foro de pesca, pesca familiar). Se invita a los coordinadores de programas de reclutamiento a capitalizar el uso que los pescadores le dan a internet, al momento de generar información disponible en red. Una selección cuidadosa de los términos que se incluyen en información disponible en la red de manera que coincida con el potencial de búsqueda de los pescadores, podría ayudar a dirigir el tráfico hacia las páginas electrónicas de las agencias estatales que patrocinan los programas de reclutamiento.

such as federal and state departments of health and education and authors of popular literary works (e.g., Louv 2005). Aside from public health concerns (McCurdy et al. 2010), declining participation in outdoor recreation has a direct and negative impact on natural resource protection. Many natural resource management agencies rely on permit sales, license sales, and usage fees to fund their efforts to maintain and protect natural areas. Declines in participation, and thus funds from license sales, can reduce the ability of these agencies to manage and protect natural resources. 


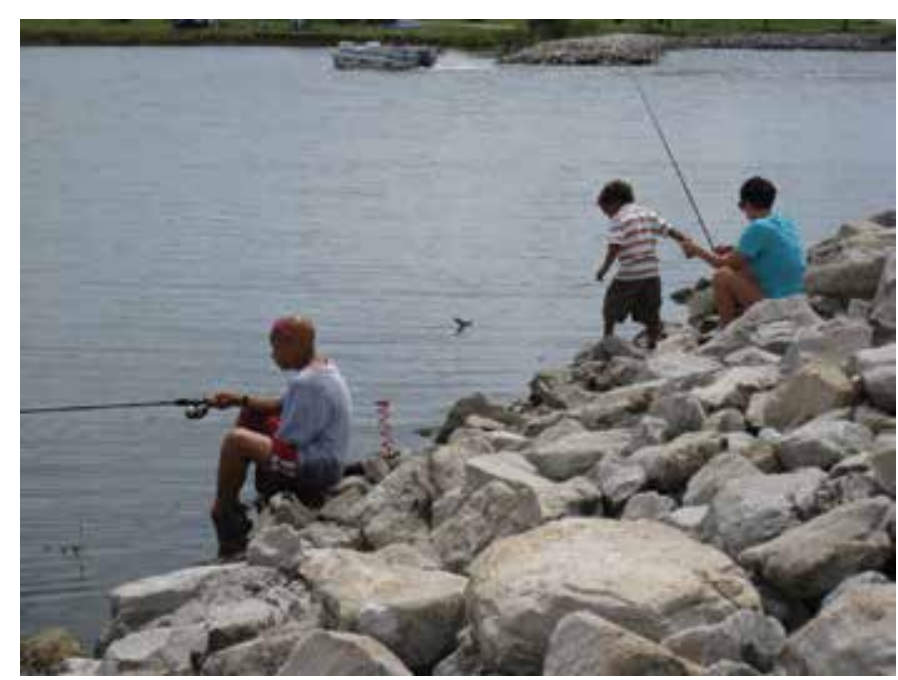

Photo 1. Family fishing day at the lake. Credit: Cliff Wilson.

Like participation in outdoor recreation in general, participation in aquatic recreational activities such as boating and angling is declining (Pergams and Zaradic 2008), leaving natural resource management agencies with the need to market aquatic activities to the public. Decreasing angling participation (U.S. Fish and Wildlife Service et al. 2006) has prompted many state agencies to launch extensive angler recruitment and retention programs (e.g., Nebraska Game and Parks Commission 2008). These often center on activities such as children's and family fishing events and free fishing weekends but also include traditional marketing campaigns. Evidence supporting gains in angler participation as a result of these current angler recruitment and retention programs is lacking. In fact, angler participation continues to decline despite these programs (U.S. Fish and Wildlife Service et al. 2006).

Increased Internet and electronic media use are often identified as critical factors in declining participation in outdoor recreation (Pergams and Zaradic 2006). However, changing means of information gathering by anglers may require aquatic resource management agencies to rely on the Internet for increasing participation in aquatic recreation. For example, anglers once exchanged information about fishing at local cafes, bait shops, and boat ramps, but they now exchange this information through online forums, discussion boards, and Facebook groups. These platforms allow contemporary anglers an expanded array of methods for gathering and sharing information. Moreover, these online platforms provide real-time information, which may come directly from someone currently fishing.

The recent and rapid development of Internet and electronic media resources has outpaced fishery managers' abilities to understand and effectively use search engines, discussion boards, Twitter feeds, and Facebook groups to reach current and potential anglers (hereafter, "angler" will refer to current and potential anglers). We examined patterns of angler behavior as evidenced by
Internet search histories to better understand how the Internet might be used for angler recruitment and retention efforts. Specifically, we examined angler-related Internet search behavior using a free web-based tool (Google Insights for Search) that summarizes Google searches since 2004 to determine (1) trends in Internet search volume for general fishing-related terms and (2) the relative effectiveness of terms related to angler recruitment and retention programs found across the United States, based on Google search patterns.

\section{METHODS}

\section{Google Insights for Search}

Google Insights for Search (hereafter, Google Insights; http:/www.google.com/insights/search) is a free, web-based tool that provides index scores for specified terms used in searches. Google Insights uses a proprietary algorithm to calculate a score for each search term that represents the likelihood a random Google user would search for that particular term (Google 2010). Google Insights can be used to compare search volume for up to five terms simultaneously and results can be filtered by any combination of category (entertainment, health, hobbies and leisure, news, etc.), location (worldwide, country, state, or metro), and time (any date range from 2004 to present). The search volume for these terms is then normalized so that the greatest value is set to 100 and all other values are scaled against that observation. Normalized scores are then averaged over the period searched to provide a single score for each search term. Consequently, mean normalized scores are directly comparable only among terms used within a given search.

Google searches are becoming a common source of current trend information in a number of disciplines. The rationale behind using search trends as a surrogate of actual trends is based on the idea that users (i.e., the general public) seek information for immediate use or action. For example, diseases such as influenza can be tracked both spatially and temporally using search volume to gather information before users actually report to the doctor for treatment (Ginsberg et al. 2009). Correlations between search volume and patient records also exist for kidney stone occurrence (Breyer et al. 2011) and the awareness of cancer following a celebrity death (Metcalfe et al. 2011). In the social science literature, search volume has
TABLE 1. List of search terms used to analyze anglers' use of Google searches for gathering information on fishing.

\begin{tabular}{|l|l|l|}
\hline Recruitment and retention terms & Fishing information terms & Social media terms \\
\hline Free fishing & Fishing report & Fishing forum \\
\hline Fishing clinic & Fishing conditions & Fishing blog \\
\hline Fishing schools & Fishing guide & Fishing Twitter \\
\hline Urban fishing & Fishing license & Fishing Facebook \\
\hline Family fishing & Fishing rules & Fishing YouTube \\
\hline Women fishing & Trophy fishing & \\
\hline Kid fishing & Fishing tournament & \\
\hline
\end{tabular}


also been found to correlate with unemployment rates (Askitas and Zimmermann 2009) and perceptions of unemployment (Scheitle 2011).

\section{Data Collection and Analysis}

Google Insights was accessed on December 15, 2011, and filtered using hobbies and leisure (category), outdoors (subcategory), United States (location), and 2004-present (time). We first examined the general search term "fishing" to explore seasonal trends and magnitude of search volume. We also examined temporal trends in 20 search terms selected by an ad hoc survey of fishery professionals and from one of three categories: (1) terms commonly used in current angler recruitment and retention programs throughout the country (e.g., Arizona Game and Fish Department 2009 and Tennessee Wildlife Resources Agency 2011), (2) fishing information gathering terms, and (3) social media terms (Table 1).

In addition to normalized scores for search volume, Google Insights returns a list of the top search terms. When these top searches included search terms with extraneous or irrelevant information, mathematical operators $(+$ and -$)$ were employed to include or exclude certain words or phrases in search terms. For example, a Google Insights search for the term "Fishing reportweather," would functionally serve as fishing report NOT weather, excluding searches that included weather from the results. Operators and terms added or excluded from searches are listed in Table 2; any references to particular search terms in discussion will exclude mention of operators.

Because mean normalized scores are not directly comparable across searches, we included either "fishing report" or "fishing forum" in every search to allow comparison of normalized scores across searches. We also compared search volume against time in days since January 11, 2004 (the earliest result displayed by Google Insight), using simple linear regression to evaluate the strength and direction of trends across the survey period.

\section{RESULTS}

Overall, searches within the "outdoors" subcategory with the "hobbies and leisure" filter applied have declined since 2004. Fishing was the most-searched term in the outdoors subcategory (Table 2; Figure 1). Search volumes for fishing and terms directly related to fishing - such as fishing guide-decreased through the period (Table 2). Search volume for most of these terms followed an annual pattern, with the greatest search volume occurring during the late spring and summer and less volume during the fall and winter (Figure 2).

Among the 20 terms analyzed, search volume was greatest for "fishing," followed by "fishing report," "fish-
Since 2004, the search volume for general

fishing terms (e.g." "fishing guide") has de-

clined. However, angling terms related to

social media (e.g., "fishing Facebook") and

angler recruitment programs (e.g̊, "family fishing") has increased.

TABLE 2. Google Insights for Search relative search volume score and slope and $\boldsymbol{P}$-value of slope (from type I sum of squares) for the relationship between search volume and time (months since January 1, 2004). Clarifying search terms are joined to primary search terms with Boolean operators and are included in parentheses.

\begin{tabular}{|c|c|c|c|}
\hline Term & Score & Slope & P-value \\
\hline \multicolumn{4}{|c|}{ Low return } \\
\hline Fishing Twitter & 1 & 0.02 & $<0.0001$ \\
\hline Urban fishing & 3 & 0.01 & 0.28 \\
\hline Trophy fishing (NOT game) & 6 & 0.04 & 0.34 \\
\hline $\begin{array}{l}\text { Fishing clinic (AND fishing class AND fishing } \\
\text { classes) }\end{array}$ & 7 & 0.05 & $<0.0001$ \\
\hline Fishing blog & 7 & 0.08 & $<0.0001$ \\
\hline Family fishing (NOT guy) & 8 & 0.06 & $<0.0001$ \\
\hline $\begin{array}{l}\text { Women fishing (NOT pictures NOT photos NOT } \\
\text { pics) }\end{array}$ & 10 & 0.05 & $<0.001$ \\
\hline $\begin{array}{l}\text { Kid fishing (AND youth fishing AND junior fishing } \\
\text { NOT games) }\end{array}$ & 11 & 0.05 & $<0.0001$ \\
\hline Fishing conditions & 11 & $<-0.01$ & 0.86 \\
\hline Fishing Facebook (NOT game) & 20 & 0.37 & $<0.0001$ \\
\hline Fishing school (AND fishing schools NOT high) & 20 & -0.01 & 0.73 \\
\hline Fishing YouTube & 22 & 0.32 & $<0.0001$ \\
\hline $\begin{array}{l}\text { Free fishing (NOT online NOT games NOT game } \\
\text { NOT videos NOT maps NOT boat NOT lures NOT } \\
\text { tackle NOT map NOT tips) }\end{array}$ & 30 & -0.03 & 0.45 \\
\hline Fishing forum ${ }^{a}$ & 57 & 0.31 & $<0.0001$ \\
\hline \multicolumn{4}{|c|}{ Medium return } \\
\hline Fishing forum ${ }^{a}$ & 7 & & \\
\hline Fishing tournament & 8 & -0.01 & 0.13 \\
\hline Fishing rules (AND fishing regulations) & 12 & -0.02 & 0.12 \\
\hline $\begin{array}{l}\text { Fishing guide (NOT WOW }{ }^{b} \text { NOT Warcraft NOT } \\
\text { cooking) }\end{array}$ & 12 & -0.06 & $<0.0001$ \\
\hline Fishing license & 40 & 0.13 & 0.04 \\
\hline Fishing report (NOT weather) ${ }^{c}$ & 63 & 0.09 & 0.13 \\
\hline \multicolumn{4}{|c|}{ High return } \\
\hline Fishing report (NOT weather) ${ }^{c}$ & 5 & & \\
\hline Fishing & 58 & -0.27 & $<0.0001$ \\
\hline
\end{tabular}

${ }^{\text {a }}$ Term included in searches to compare between low-return and medium-return searches. ${ }^{\mathrm{b}} \mathrm{WOW}=$ World of Warcraft, a popular video game containing a fishing subroutine. 'Term included in searches to compare between medium-return and high-return searches.

ing license," "fishing guide," and "fishing rules" (Table 2). Internet search volume related to social media sites including "fishing Facebook," "fishing Twitter," and "fishing YouTube" increased over time (Table 2; Figure 2). Terms used in angler recruitment and retention programs were among the least searched in our study (e.g., "urban fishing," "kid fishing," "women fishing," "fishing clinic," "fishing school") and all 


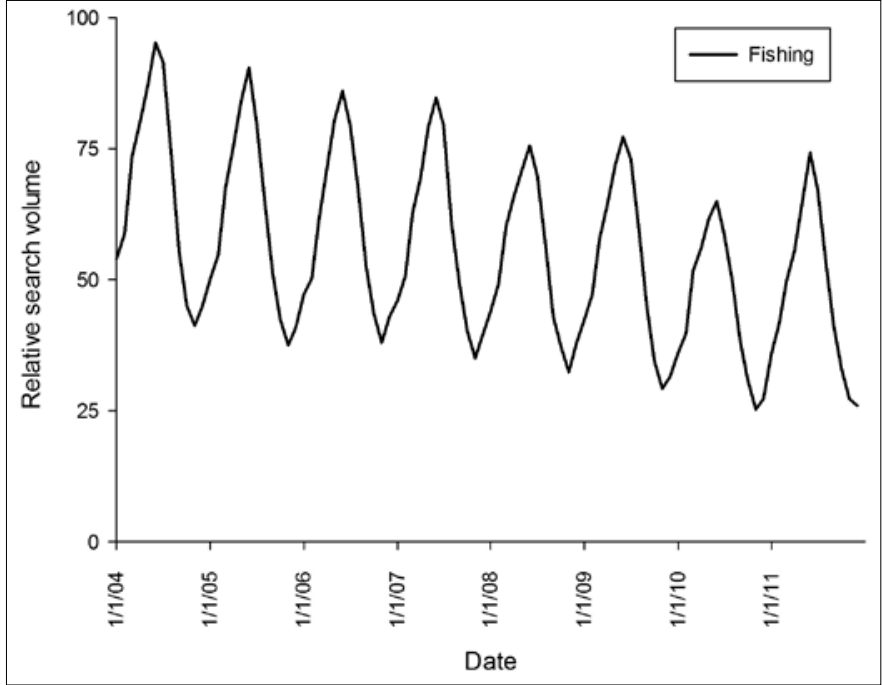

Figure 1. Relative search volume for "fishing" in the outdoors category of Google Insights for Search from 2004 to present.

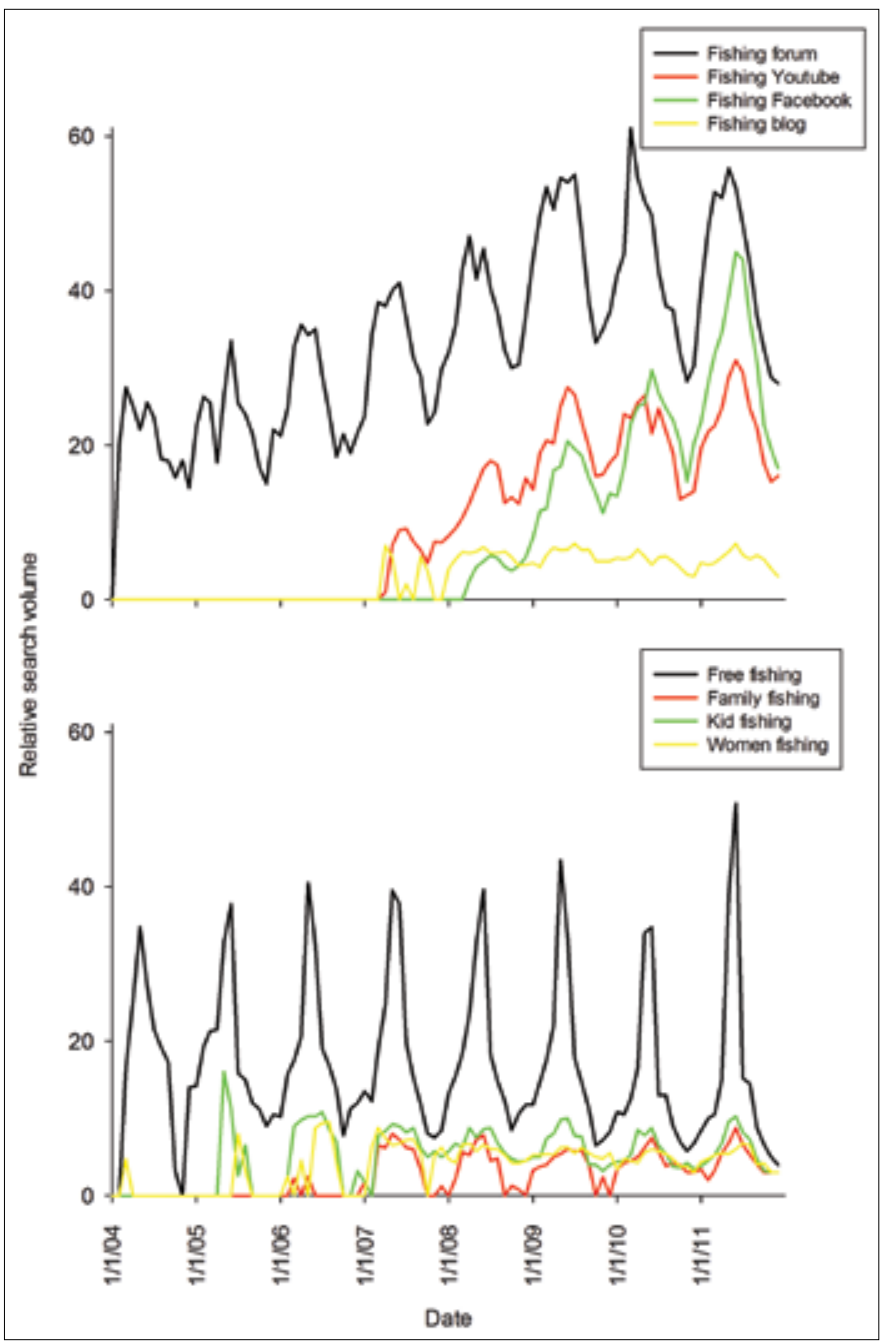

Figure 2. Relative search volume for four social media terms (top panel) and four recruitment and retention program terms (bottom panel) in the outdoors category of Google Insights for Search from 2004 to present. ranked low in search volume (Table 2). However, search volume for these terms generally increased despite evidence of a declining interest in fishing overall (Table 2; Figure 2).

\section{DISCUSSION}

Current and potential anglers use the Internet to find angling-related information as demonstrated by increasing search volume for fishing-related terms. For example, "fishing report," a phrase that could be searched by an angler looking for local fishing conditions, had the highest relative score of any specific term searched in our study. Anglers also commonly use Internet resources as a means of exchanging fishing information, ranging from the basic "what, when, and where" questions of fishing in their area to the intricate questions of "how," including information on fishing licenses, rules, and regulations.

Increases in search volume for fishing in social media outlets provide evidence that forums, blogs, and websites like YouTube and Facebook are becoming increasingly important to anglers. As Internet use on mobile phones increases, social media sites can provide a real-time exchange of information about current fishing conditions and a chance for anglers to share pictures and information while still on the water. Social media outlets appear to be used by both avid and casual anglers but are likely used by anglers in varying capacities (Recreational Boating and Fishing Foundation 2010), and understanding these differences in usage patterns is important for management agencies developing recruitment and retention programs. Casual anglers, for example, are more likely to post their angling experiences on Facebook and Twitter, whereas avid anglers are more likely to participate in discussions on angling blogs and outdoor forum discussion boards (Recreational Boating and Fishing Foundation 2010). Furthermore, there is a switch from use of general search terms such as "fishing" and "recreation" to specific fishing-related social media terms that may be indicative of a shift in the tools that anglers are using to find information. Natural resource management agencies should encourage the use of social media within their organizations and encourage the use of information exchange on social media sites. The private business sector, for example, has found social media presence to serve as a valuable means of advertisement (Mangold and Faulds 2009). This model may also prove valuable to natural resource management agencies.

Agencies using the Internet and electronic media in their recruitment and retention strategies must have a firm understanding of the search terms used by anglers to ensure that the target audience can find information about agency products. Understanding which terms are used in search queries by persons interested in fishing will allow natural resource management agencies to tailor website information to capitalize on existing patterns of angler behavior and ultimately increase information delivery to their target audience. Additionally, if agencies do not use common search terms to describe angler programs on the Internet, interested persons will have difficulty locating that information. Search engines can only search for those terms present on a website; consequently, information re- 


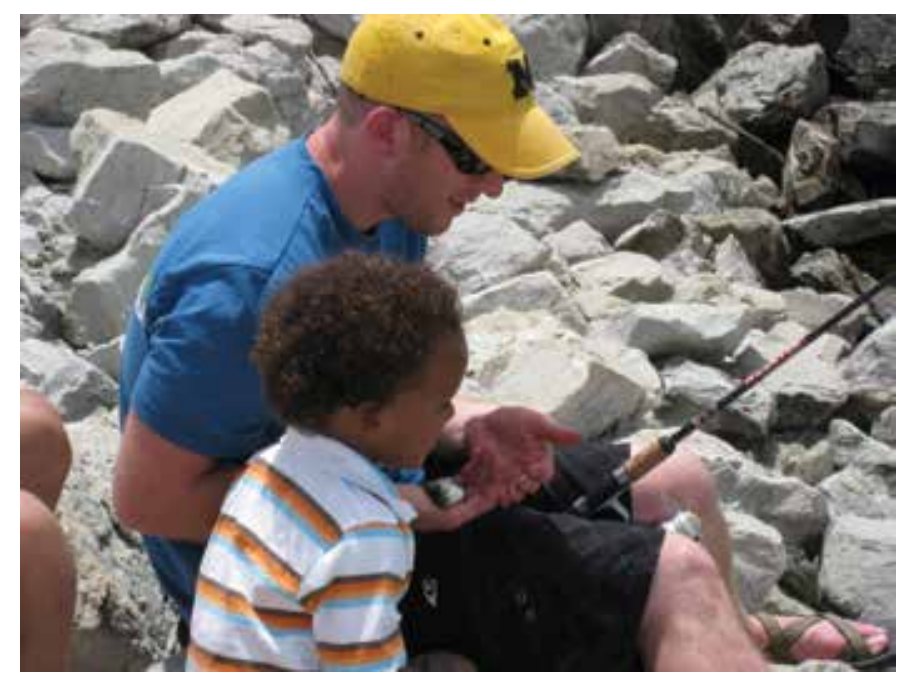

Photo 2. First fish of the day. Credit: Cliff Wilson.

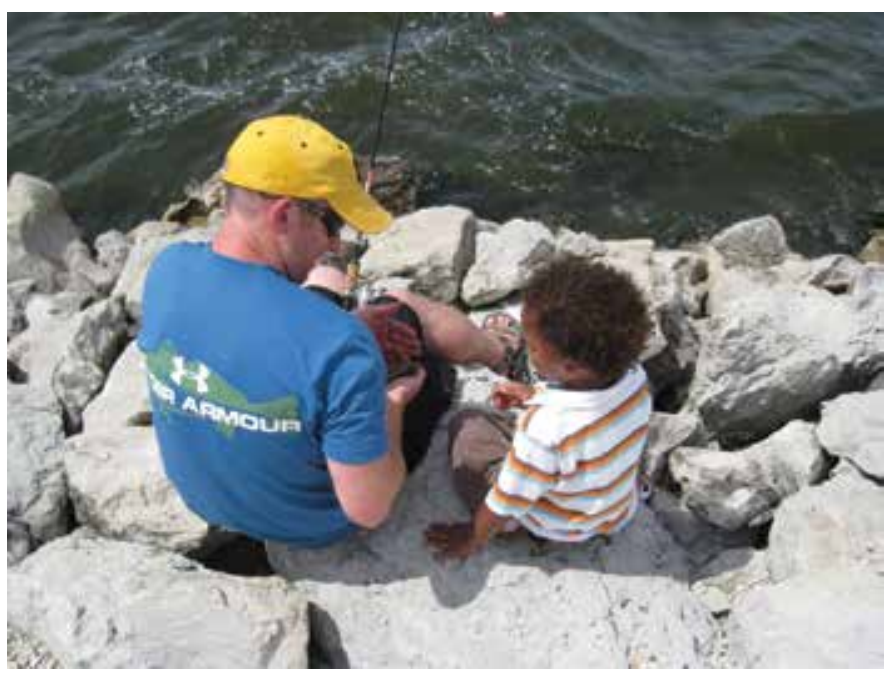

Photo 3. Learning about fish. Credit: Cliff Wilson.

garding angler recruitment and retention programs should be presented using unambiguous terms, avoiding jargon, to maximize the chances of potential anglers locating the information. Web pages presenting information on recruitment and retention events, for example, or programs phrased "free fishing" had greater search volume than programs phrased as "fishing clinic," "urban fishing," "women fishing," and "kid fishing." Existing agency programs may benefit from relabeling so they are more likely to include search terms used by anglers. For instance, Internet searches for "fishing guide," a phrase used by many natural resource management agencies to describe documents containing fishing regulations, is used by persons seeking information on guided fishing trips. The inability of anglers to easily locate basic fishing information may lead to confusion, frustration, and potentially alienation. Studying fishing-related Internet searches allows for a simple analysis of the top searches for recruitment and retention terms, thus enabling state agencies to present or label information with the specific search terms used by anglers.
Google Insights can provide an understanding into angler behavior for natural resource management agencies that is now possible at previously immeasurable scales (Arlinghaus and Cooke 2008), although it does have two key limitations. First, the demographics of Internet users and the angling population may be different. Internet use is greater among younger generations (e.g., $87 \%$ by millennials) than older generations (e.g., $70 \%$ by older baby boomers; Jones 2009). The population of anglers is much older than the population of Internet users. We believe that this bias is minimal in the context of our study because our objective was to examine search terms related to recruitment programs and most recruitment programs are aimed at recruiting young anglers and keeping them in the angling population. Second, results from Google Insights are sensitive to search term selection. It is imperative to examine the top searches listed to look for influential outliers that may need to be excluded. For example, a search for "fishing guide" returns a top search of "wow fishing guide." When searching for this term, we found that this is a user guide for a popular video game, World of Warcraft. Natural resource management agencies must be (as this example demonstrates) especially mindful of terminology used in their Internet sources of information.

Declining participation in outdoor recreation has left natural resource management agencies scrambling to find the new anglers to fund natural resource protection and management. The fate of this funding likely rests with younger people who regularly use the Internet to obtain information that will enhance and improve their activities in their day-to-day lives. Reaching the next generation will require natural resource management agencies to embrace these technologies rather than simply blaming technology for decreasing angler participation. Searches for outdoor recreational activities are increasing at a time when participation is decreasing, thus demonstrating that by eschewing the Internet natural resource agencies may be missing an opportunity and venue to recruit and retain anglers. Strategic use of the Internet now may help natural resource management agencies recruit the next generation of anglers and retain funding for the protection of our natural resources into the future.

\section{ACKNOWLEDGMENTS}

We thank Ben Beardmore, Andrea Faas, and Keith Hurley for helpful comments on earlier drafts of this article. Many of the ideas presented here originated while working on Federal Aid in Sport Fish Restoration project F-182-R, which was administered by the Nebraska Game and Parks Commission. Any use of trade names is for descriptive purposes only and does not imply endorsement by the U.S. Government. The Nebraska Cooperative Fish and Wildlife Research Unit is jointly supported by a cooperative agreement among the U.S. Geological Survey, the Nebraska Game and Parks Commission, the University of Nebraska, the U.S. Fish and Wildlife Service, and the Wildlife Management Institute. 


\section{REFERENCES}

AGFD (Arizona Game and Fish Department). 2009. Urban Fishing Program overview. Available: http://www.azgfd.gov/h_f/urban_ overview.shtml. (January 2011).

Arlinghaus, R. A., and S. J. Cooke. 2008. Recreational fishing: socio-economic importance, conservation issues and management challenges. Pages 39-58 in B. Dickson, J. Hutton, and B. Adams, editors. Recreational hunting, conservation and rural livelihoods: science and practice. Blackwell Publishing, Oxford, U.K.

Askitas, N., and K. F. Zimmermann. 2009. Google econometrics and unemployment forecasting. Applied Economics Quarterly 55:107-120.

Breyer, B. N., S. Sen, D. S. Aaronson, M. L. Stoller, B. A. Erickson, and M. L. Eisenberg. 2011. Use of Google Insights for Search to track seasonal and geographic kidney stone incidence in the United States. Urology 78:267-271.

Ginsberg, J., M. H. Mohebbi, R. S. Patel, L. Brammer, M. S. Smolinski, and L. Brilliant. 2009. Detecting influenza epidemics using search engine query data. Nature 457:1012-1014.

Google. 2010. Google Insights for Search help. Available: http://www. google.com/support/insights/. (December 2010).

Jones, S. 2009. Generations online in 2009. Pew Internet \& American Life Project. Available: http://pewinternet.org/Reports/2009/ Generations-Online-in-2009.aspx. (February 2012).

Kareiva, P. 2008. Ominous trends in nature recreation. Proceedings of the National Academy of Sciences 105:2757-2758.

Louv, R. 2005. Last child in the woods: saving our children from nature-deficit disorder. Algonquin Books, Chapel Hill, North Carolina.

Mangold, W. G., and D. J. Faulds. 2009. Social media: the new hybrid element of the promotion mix. Business Horizons 52:357-365.

McCurdy, L. E., K. E. Winterbottom, S. S. Mehta, and J. R. Roberts. 2010. Using nature and outdoor activity to improve children's health. Current Problems in Pediatric and Adolescent Health Care 40:102-117.

Metcalfe, D., C. Price, and J. Powell. 2011. Media coverage and public reaction to a celebrity cancer diagnosis. Journal of Public Health $33: 80-85$.

NGPC (Nebraska Game and Parks Commission). 2008. A 20-year plan for hunter/angler recruitment, development, and retention in Nebraska. Nebraska Game and Parks Commission, Lincoln, Nebraska.

Pergams, O. R. W., and P. A. Zaradic. 2006. Is love of nature in the U.S. becoming love of electronic media? 16-Year downtrend in national park visits explained by watching movies, playing video games, Internet use, and oil prices. Journal of Environmental Management 80:387-393.

Pergams, O. R. W., and P. A. Zaradic. 2008. Evidence for a fundamental and pervasive shift away from nature-based recreation. Proceedings of the National Academy of Sciences 105:2295-2300.

RBFF (Recreational Boating and Fishing Foundation). 2010. Boating and fishing social media audit. Available: http://www.tn.gov/ twra/fish/pond/TWRAfamlake.html. (December 2010).

Scheitle, C. P. 2011. Google's Insights for Search. A note evaluating the use of search engine data in social research. Social Science Quarterly 92:285-295.

TWRA (Tennessee Wildlife Resources Agency). 2011. TWRA family fishing lakes. Tennessee Wildlife Resources Agency, Nashville, Tennessee. Available: http://www.rbff.org/page.cfm?pageID=26. Accessed January 2011.

USFWS (U.S. Fish and Wildlife Service), U.S. Department of Commerce, and U.S. Census Bureau. 2006. 2006 National Survey of Fishing Hunting and Wildlife-Associated Recreation.

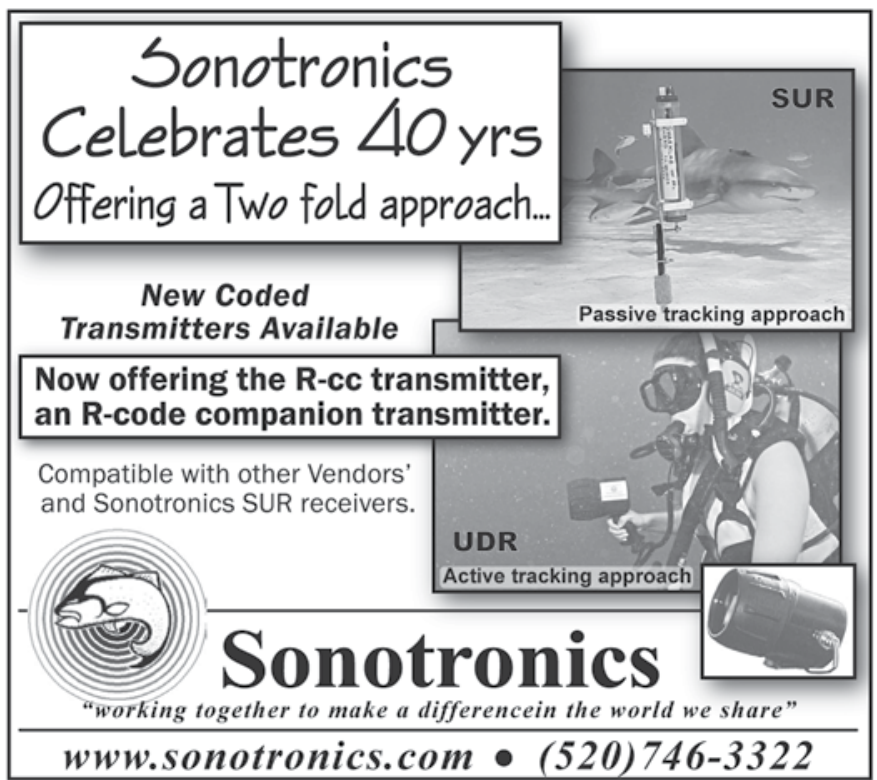

\section{Stream Count ${ }^{\mathrm{m}}$ Drysuits and Travel Waders ${ }^{\mathrm{m}}$}

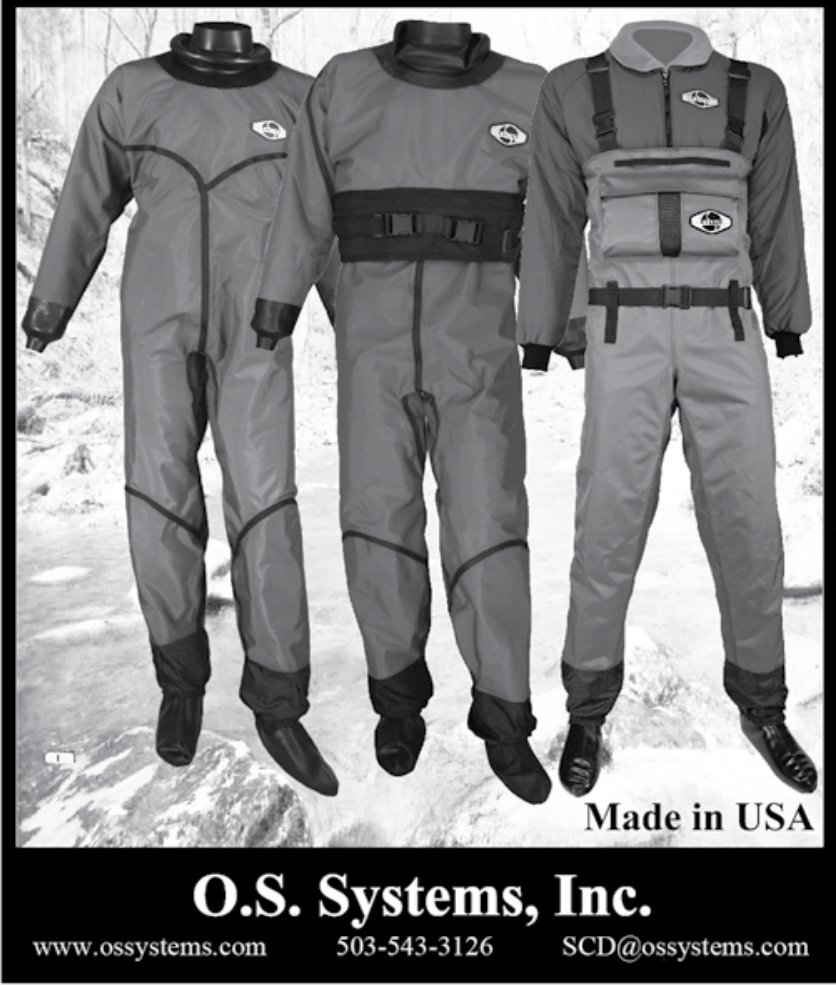

